\author{
Zh.Yu. Sergieieva ${ }^{1}$, F.I. Tovkach ${ }^{2}$ \\ ${ }^{1}$ Odesa I.I. Mechnikov National University, \\ 2 Dvoryanska St., Odesa, 65082, Ukraine, \\ ${ }^{2}$ D.K. Zabolotny Institute of Microbiology and Virology of NASU, \\ 154 Zabolotny St., Kyiv, 03143, Ukraine
}

\title{
PHYTOPATHOGENIC BACTERIUM PECTOBACTERIUM CAROTOVORUM CRYPTIC PLASMIDS DISTRIBUTION
}

Information on the extrachromosomal elements occurrence in phytopathogenic bacterium Pectobacterium carotovorum is insufficiently presented in modern scientific literature. Data on the pectobacteria plasmid content are random. The aim was to study the Pectobacterium carotovorum plasmids spectra, cryptic plasmids distribution and general characteristics. Materials and methods. Plasmid spectra of 54 strains of different origins were studied. Standard hot alkaline Kado and Liu method was used to isolate plasmids DNA [Kado C.J., Liu S.-T. Rapid procedure for detection and isolation of large and small plasmids. J. Bacteriol. 1981; 145 (3): 1365-1373]. Results. It was found that 16 strains contained plasmids of various sizes. Isolated plasmids belonged to four discrete size classes: 2.5-6.8, 9.8-16.7, 47.7-64.5 and $129 \mathrm{~kb}$. Approximately $50 \%$ of the isolated P. carotovorum plasmids belonged to the second discrete size class with a size of 8.7-10.4 kb. Four large $129 \mathrm{~kb}$ P. carotovorum plasmids had unique primary DNA sequence according to results of restriction analysis. Conclusions. Pectobacteria plasmids isolation results correlate with data obtained earlier that $30 \%$ of strains contained plasmids [Tovkach FI. [Isolation and preliminary characterization of cryptic plasmids from Erwinia carotovora]. Microbiology. 2001; 70 (6): 804-810. Russian]. Strains ` plasmid maintenance was associated with environmental and ecological niches where bacteria persisted. These extrachromosomal DNAs may present silent "selfish", and probably prophage, replicons.

K e y w ords: Pectobacterium carotovorum, cryptic plasmids, restriction analysis, ecology, species `plasmids spectra

Extrachromosomal DNAs are widely spread among Enterobacteriaceae family members and play an important role in the bacteria ecology and pathology [12]. Phytopathogenic bacterium Pectobacterium carotovorum forms a complex taxon which includes strains with different phenotypic, biochemical, genetic and plant-pathogen interactions characteristics, which allows dividing this species to several subspecies [11, 13].

Plasmid spectrum (or profile) is an important species characteristic, based on the specific set of plasmids in the cell. Strains may lose some of the plasmids, but species typical basic set remains unchanged [6].

Pectobacteria strains plasmids spectra are strictly species specific for this bacteria species in nature. The circular DNA plasmids presence was revealed for most bacterial pathogens however, for a significant number of identified plasmids functions remained unclear, which is also true for pectobacteria cryptic plasmids. Usually plasmids make up on between $2 \%$ and $30 \%$ of the total bacterial genome in size $[10,14]$.

Pectobacterium genus bacteria can inhabit the plants surface, soil, water as symbiotic microorganisms, but mostly they are host plants pathogens. P. caro- 
tovorum subsp. carotovorum (Pcc) can cause soft rot on cabbage, potato and carrot roots and tubers and closely related $P$. carotovorum subsp. atrosepticum (Pca) can cause plants "black leg" [8, 10].

Autonomous genetic elements involvement in the formation of new bacterial variants by horizontal pathogenicity gene transfer is the undisputed scientific fact of modern bacteriology. Due to the genes transfer between related bacteria, that inhabit a particular ecological niche, their adaptive capacity is extended, and biodiversity is formed. $P$. carotovorum genetic determinants responsible for adaptational ability and pathogenic potential associated with plasmids or phages pathogenicity islands still have not been identified [11, 13, 14].

The research was carried out to study plasmids spectra, distribution and characteristics of $P$. carotovorum strains cryptic plasmids.

Materials and methods. Plasmid profiles of 54 P. carotovorum strains of different origins (Ukraine, Belarus, Russia, Armenia, Romania, Czech Republic, Belgium) were studied: P. carotovorum subsp. carotovorum-48A, 75, 144 a, 482 E, 741, 808 a, 7869, NCPPB 550, 718, 566 BKM, 246, 915, 184, 2, 48П, 53П, 91П, 921, 2054, ATCC $27388=$ NCPPB 1065, G 147, G 117, 258, 133, 5, 180, 495, ATCC $15713^{\mathrm{T}}=\mathrm{NCPPB} 312^{\mathrm{T}}$ (T-type strain), NCPPB 438, SR165, E193, 162, 209, Cc 110, 33A, 13A/15, 4', 9', 10', 11', 16', 18', 3', 15', 23'; P. carotovorum subsp. atrosepticum $-58 \mathrm{~A}$, NCPPB 549 ${ }^{\mathrm{T}}=\mathrm{ATCC} 33260^{\mathrm{T}}$, 9Ф, g217, 5A, 37A, 40A, 46A, 194-8; E. carotovora subsp. «toxica» 47 a, K-47. Agrobacterium tumefaciens C58 pTi-C58 plasmid (188 kb) and Escherichia coli K12 F plasmid (100 kb) and RP4 plasmid (60 kb), E. coli J53 were used as markers in determining the large extra-chromosomal DNAs size.

A standard hot alkaline Kado and Liu method was used to isolate plasmid DNA [9], but with an important modification. Reproducible results were obtained due to the method's adequacy and universality. However, the P. carotovorum plasmid DNA isolation required two- or threefold centrifugation for the aqueous and phenolic phases separation due to the strains mucous material presence after several repeated mixings with phenol. In rare cases, it was not possible to isolate strain`s plasmid due to the cells ' high nuclease activity. Also, the pectobacteria plasmids isolation was followed by chromosome less degradation, which affected the track purity during electrophoresis.

$P$. carotovorum plasmids isolation using Kado and Liu method was adequate, and thus obtained plasmid DNAs were suitable for further molecular genetic studies, including restriction analysis. HpaI, BglI, SalI, EcoRI, EcoRV and $P s t \mathrm{I}$ endonucleases were used for restriction analysis. Plasmid copy number was determined using an analytical transilluminator «BioRad Molecular Imager Doc XR + imaging system» and «Quantity One» program.

Results. Comparison of plasmid DNA samples isolation from bacterial cells grown on solid and liquid nutrient media showed, that cells grown on liquid medium contained more plasmid material. It was found that $P$. carotovorum cells grown on $1 \%$ pectin liquid selective medium contained more plasmid DNA and these samples ' bacterial chromosome eliminated better. However, it was true only in case of small plasmids isolation. $P$. carotovorum large plasmids' samples, isolated from cells grown on pectin, contained minimal amounts of the chromosomal DNA impurities compared with samples isolated from cultures grown on plates [2].

It was found that 16 of 54 tested strains contained plasmids of various sizes. 
Isolated plasmids belonged to four discrete size classes: $2.5-6.8,9.8-16.7$, $47.7-64.5$ and $129 \mathrm{~kb}$. Approximately $50 \%$ of the isolated $P$. carotovorum plasmids belonged to the second class and had a discrete size $9.8 \mathrm{~kb}$. These plasmids copy number was about $8-13$ molecules per cell. Next by the occurrence frequency went large $129 \mathrm{~kb}$ plasmids. They were found in $P$. carotovorum subsp. carotovorum 194-8, NCPPB 312 ${ }^{\mathrm{T}}$, 33A and P. carotovorum subsp. atrosepticum NCPPB $549^{\mathrm{T}}$ and g217. Plasmids 47.7 and $64.5 \mathrm{~kb}$ in size had sporadic occurrence. $47.7 \mathrm{~kb}$ plasmid was isolated from NCPPB $549^{\mathrm{T}}=$ ATCC $33260^{\mathrm{T}}$ strain, and $64.5 \mathrm{~kb}$ plasmid was isolated from NCPPB $312^{\mathrm{T}}=$ ATCC $15713^{\mathrm{T}}$ strain (Fig. 1, 2).

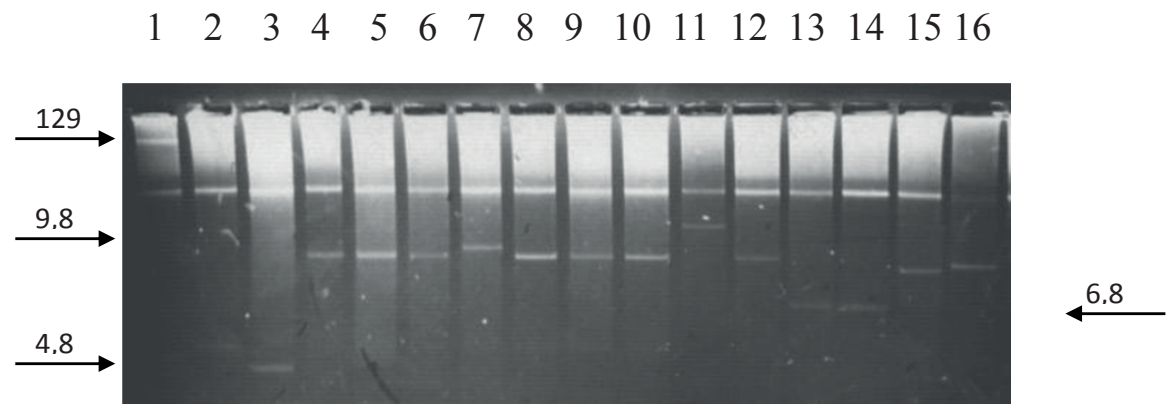

Fig. 1. $P$. carotovorum 3.8 - 16.7 kb plasmids electrophoregram: 33A(1), 495 (2), 3 ` (3), 2 (4), 75 (5), 48A(pCA25) (6), 921 (7), G147 (8), 718 (9), 566 ВКМ (10), 48A(pCA25::Tn9) (11), 246 (12), 184 (13), 16 (14), 23 (15) and E. coli (pLOF; $9,9 \mathrm{~kb})$ (16)

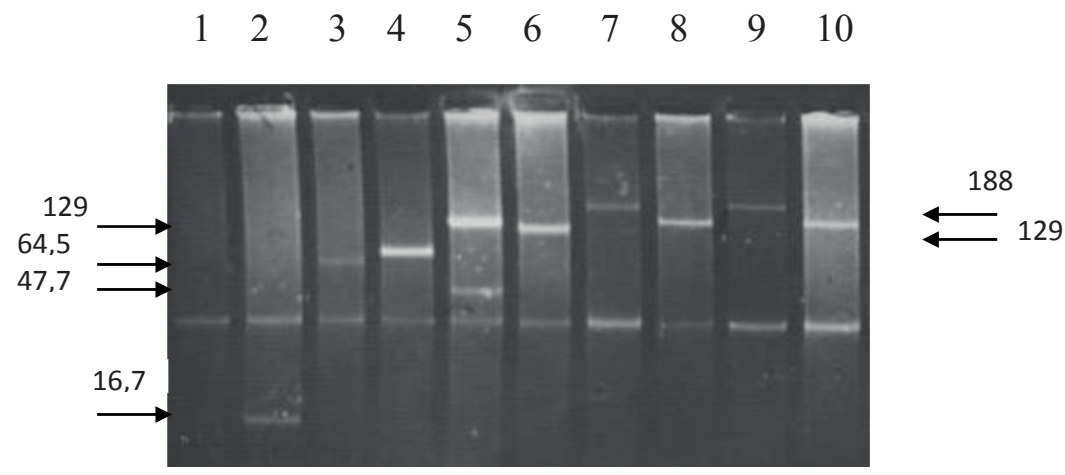

Fig. 2. P. carotovorum subsp. carotovorum large plasmids electrophoregram: 194-8 (1), NCPPB 312 ${ }^{\mathrm{T}}$ (4), 33A (129 kb) (10); P. carotovorum subsp. atrosepticum: 9Ф (2), NCPPB 549 (5), g217(8); E. coli: J53 (RP4) (3), K12 (F) (6); A. tumefaciens: C58 (pTi-C58) $(7,9)$

P. carotovorum 48A(pCA25), 2, 75, 921, G 147, 718, 566 BKM, 48A(pCA25::Tn9), 246, 184 strains extrachromosomal DNAs restriction analysis via HpaI and EcoRV endonucleases showed that these genetic elements had restriction sites homology. The difference in the restriction fragments sizes resulted only from the original difference in plasmids` sizes due to the deletioninsertion mutations type presence (Fig. 3). 


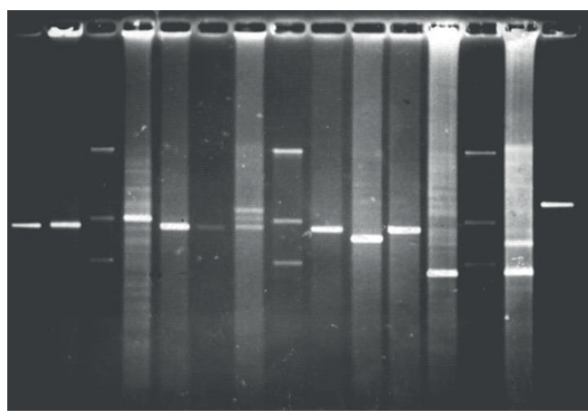

HpaI

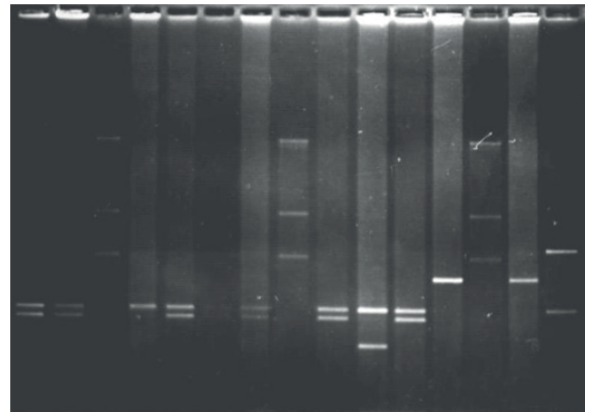

EcoRV

Fig. 3. P. carotovorum plasmids $H p a I$ and $E c o R V$ restriction fragments electrophoregram: 2 (1), 75 (2), 921 (4), G147 (5), 718 (6), 566 ВКМ (7), 246 (9), $23^{\prime}$ (10), 48A(pCA25) (11), 184 (12), 16 (14), 48A-7/4b (pCA25::Tn9) (15); control 3, 8, 13- $/$ /HindIII

Four P. carotovorum large plasmids restriction analysis with SalI, HpaI and EcoRI endonucleases revealed that each large plasmid DNA had a unique primary sequence (Table 1). Due to the several plasmids presence in the strains only the upper electrophoregram fragments ranging from 25 to $9 \mathrm{~kb}$ in size, which presented the large plasmids restriction fragments, were compared. It was established that pCA16-1, pCA42-1 и pCA549-1 plasmids DNAs had restriction sites for each of the three restriction endonucleases used (SalI, HpaI and $E c o \mathrm{RI})$. The results indicated that the large plasmids restriction patterns were unique. Thus, unlike $P$. carotovorum plasmids of about $10 \mathrm{~kb}$ in size with a similar restriction patterns, all the studied large plasmid were presented by unique sequences.

Table 1

\section{Large plasmids of $P$. carotovorum strains}

\begin{tabular}{|c|c|c|}
\hline Strain & Plasmid & Molecule length, kb \\
\hline 33A & pCA16-1 & 129 \\
& pCA16-2 & 5.3 \\
\hline NCPPB 549 & pCA 549-1 & 129 \\
& pCA 549-2 & 47.7 \\
\hline NCPPB 312 & pCA 312-1 & 64,5 \\
& pCA 312-2 & 3.8 \\
\hline C366 & pCA 42-1 & 129 \\
& pCA 42-2 & 4.3 \\
\hline
\end{tabular}

P. carotovorum strains plasmids presence screening revealed that most of the small extrachromosomal DNAs had a size of $9.8 \mathrm{~kb}$ or close to it (Fig. 4). One of the most studied $P$. carotovorum genetic elements is pCA25 plasmid [1] also having a size of $9.8 \mathrm{~kb}$. The previous data support the suggestion of its prophage nature $[1,4,5]$. pCA25 plasmid variant - pCA25::Tn9 - containing the Tn9 transposon was used for physical mapping. As a result of restriction analysis, it was found that the transposon integrated into a specific locus on a plasmid pCA25 DNA. Similarly, transposons integrate into prophage genomes non-essential regions. Plasmid pCA25 size is close to the size of the E. coli 


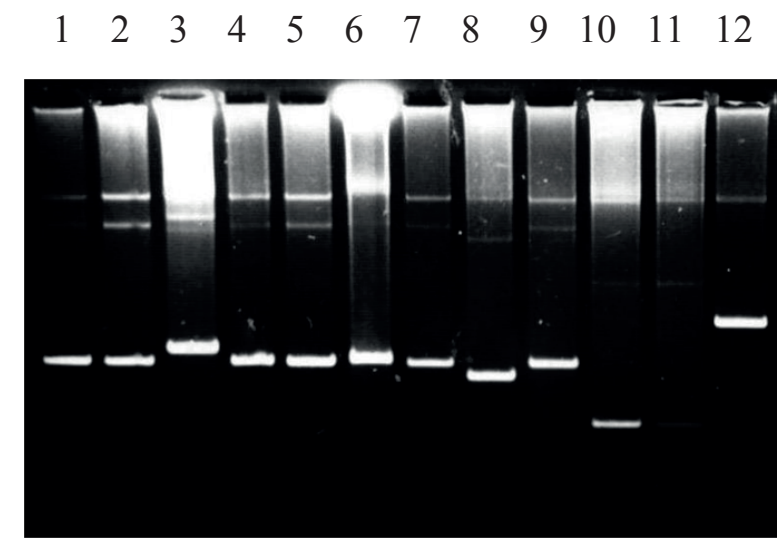

Fig. 4. P. carotovorum plasmids DNA electrophoregram: 2 (1), 75 (2), 921 (3), G147 (4), 718 (5), 566 ВКМ (6), 246 (7), 23` (8), 48A(pCA25) (9), 184 (10), 16 (11), 48A 7/4b (pCA25::Tn9) (12)

circular prophage P4 (11.6 kb) [1]. In addition, plasmid pCA25 deletion and insertion variants, isolated from other strains, have genome size changes detected in the same region, where transposon $\operatorname{Tn} 9$ insertion occurs in the strain $48 \mathrm{~A} 7 / 4 \mathrm{~b}$ and its clones.

All three HpaI sites were located in a short distance from each other, thus resulting in one large and two smaller fragments appearance (Table 2). BglI site was located in the area between the HpaI sites (Table. 2). These BglI and HpaI sites were located within EcoRV A fragment, in just a short distance from one of three EcoRV sites. It was found that the Tn9 transposon integrated pCA25 DNA in the EcoRV B fragment, also in a short distance from the EcoRV restriction site. Transposon Tn9 insertion only into plasmid pCA25 DNA's certain region was confirmed by the study of a significant plasmid pCA25::Tn 9 clones number, which were independently obtained. EcoRI and PstI sites were not found on pCA25 plasmid DNA. There is one EcoRI site CAT gene located on the Tn9 transposon DNA in plasmid pCA25::Tn9, and two PstI sites located within the $\operatorname{Tn} 9$ transposon IS1 sequences.

Table 2

Plasmids pCA25 and pCA25:: Tn9 DNA restriction fragments sizes

\begin{tabular}{|c|c|c|c|c|c|c|c|c|c|c|}
\hline \multirow[b]{2}{*}{ 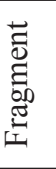 } & \multicolumn{10}{|c|}{ Hydrolysis option } \\
\hline & $\begin{array}{c}\text { BglI } \\
+ \\
\text { EcoRI } \\
\end{array}$ & $\begin{array}{c}\text { EcoRI } \\
+ \\
H p a \mathrm{I} \\
\end{array}$ & $\begin{array}{c}H p a \mathrm{I}+ \\
B g l \mathrm{I}\end{array}$ & $\begin{array}{c}B g l \mathrm{I}+ \\
P s t \mathrm{I}\end{array}$ & $\begin{array}{c}\text { EcoRI } \\
+ \\
\text { Pst } \mathrm{I} \\
\end{array}$ & $\begin{array}{c}H p a \mathrm{I}+ \\
P s t \mathrm{I}\end{array}$ & $\begin{array}{l}B g l \mathrm{I}+ \\
\text { EcoRI } \\
+ \text { PstI } \\
\end{array}$ & $\begin{array}{c}\text { EcoRV } \\
+ \\
B g l \mathrm{I}\end{array}$ & $\begin{array}{c}\text { EcoRV } \\
+ \\
\text { HpaI } \\
\end{array}$ & $\begin{array}{c}\text { EcoRV } \\
+ \\
\text { EcoRI }\end{array}$ \\
\hline \multicolumn{11}{|c|}{ pCA25 } \\
\hline A & 9.8 & 9.2 & 9.2 & 9.8 & - & 9.2 & 9.8 & 4.55 & 3.2 & 4.7 \\
\hline $\mathrm{B}$ & - & 0.4 & 0.25 & - & - & 0.4 & - & 4.5 & 4.5 & 4.5 \\
\hline $\mathrm{C}$ & - & 0.2 & 0.2 & - & - & 0.2 & - & 0.65 & 0.65 & 0.65 \\
\hline D & - & - & 0.15 & - & - & - & - & 0.15 & - & - \\
\hline \multicolumn{11}{|c|}{ pCA25:: Tn9 } \\
\hline $\mathrm{A}$ & 8.3 & 8.9 & 11.4 & 8.3 & 10.5 & 8.8 & 7.9 & 4.5 & 3.2 & 4.7 \\
\hline $\mathrm{B}$ & 4.1 & 0.4 & 0.35 & 2.7 & 1.9 & 6.8 & 2.7 & 7.1 & 7.1 & 5.3 \\
\hline $\mathrm{C}$ & - & 0.2 & 0.2 & 1.7 & - & 4.3 & 1.9 & 0.65 & 0.65 & 0.65 \\
\hline $\mathrm{D}$ & - & 3.0 & 0.15 & - & - & - & - & 0.15 & 0.45 & 1.85 \\
\hline
\end{tabular}

Note: Numbers indicate the fragments` size in kb .; "-" - the absence of fragment or fragment was not identified. 
Discussion. Pectobacteria plasmids isolation results coincide with earlier data showing that $30 \%$ of strains contained plasmids [7].

A comparative study of plasmids intra-species distribution by molecular weight for two representatives of the Enterobacteriaceae family showed that $E$. coli and $P$. carotovorum strains plasmids profiles differed greatly (Fig. 5, 6) [12].

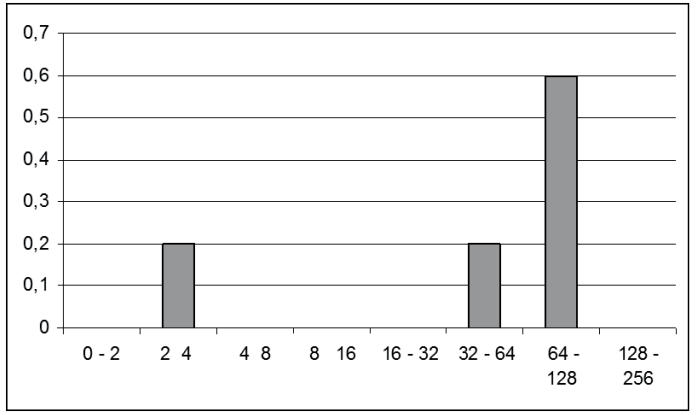

Fig. 5. E. coli strains plasmid profiles

The most common E. coli strains plasmids were falling in a group with the size range $64-128 \mathrm{~kb}$. This feature differed from the $P$. carotovorum subsp. carotovorum (Pss) and P. carotovorum subsp. atrosepticum (Psa) plasmid profiles, which plasmids, falling into a group of 64-128 kb, were the exception rather than regularity (Fig. 5). The pectobacteria characteristic indicator was the large $129 \mathrm{~kb}$ plasmids 'presence, that were not found in E. coli strains. Furthermore, pectobacteria plasmids also fall within the size ranges from $4 \mathrm{~kb}$ up to $32 \mathrm{~kb}$, that was the most typical for Pcc strains and not typical for all $E$. coli strains (Fig. 6).

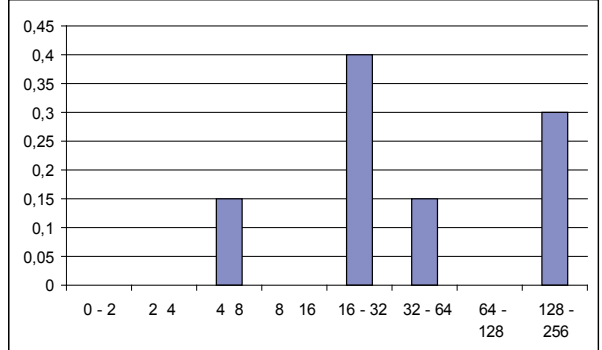

Pca

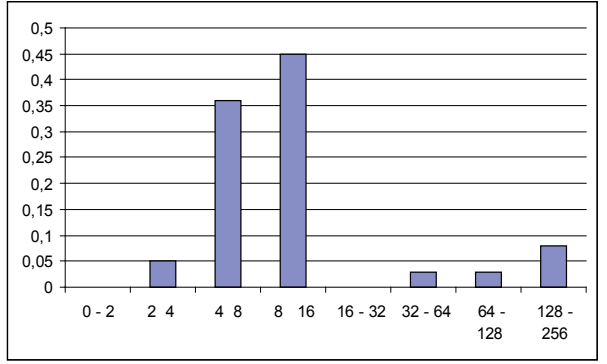

Pcc

Fig. 6. $P$. carotovorum subsp. atrosepticum (Pca) and $P$. carotovorum subsp. carotovorum (Pcc) strains plasmid profiles

It was discovered that $P$. carotovorum plasmids of the same size class were found in strains isolated from a particular ecological niche (Table 3). Half of the strains carrying $9.8 \mathrm{~kb}$ plasmid or its natural insertion-deletion variants were from Russian collections and obtained on the territory of Russia. The rest of the strains of this group were identified on the territory of Ukraine, Armenia and Romania. Pectobacteria strains from Canada carried no plasmids. With a 
single exception, strains, that were isolated on the territory of Belarus, also carried no plasmids. Large plasmids were detected in the strains of the Belgian and Czech collection of microorganisms (Table 3 ).

Table 3

Plasmid composition of $P$. carotovorum strains

\begin{tabular}{|c|c|c|c|}
\hline Strain & Plasmid & Size, $\mathrm{kb}$ & Geographic area \\
\hline 75 & pCA 75 & 9.8 & Russia \\
\hline 718 & pCA 718 & 9.8 & Russia \\
\hline 566 ВКМ & pCA 566 & 9.8 & Russia \\
\hline 246 & pCA 246 & 9.8 & Russia \\
\hline 2 & pCA 2 & 9.8 & Russia \\
\hline 184 & pCA 184 & 6.8 & Ukraine \\
\hline 921 & pCA 921 & 10.4 & Armenia \\
\hline G147 & pCA 147 & 9.8 & Romania \\
\hline 495 & pCA 495 & 5.8 & Russia \\
\hline NCPPB $312^{\mathrm{T}}$ & $\begin{array}{l}\text { pCA 312-1 } \\
\text { pCA 312-2 }\end{array}$ & $\begin{array}{c}64.5 \\
3.8 \\
\end{array}$ & Czech Republic \\
\hline NCPPB 549 & $\begin{array}{l}\text { pAT 549-1 } \\
\text { pAT 549-2 }\end{array}$ & $\begin{array}{l}129 \\
47.7 \\
\end{array}$ & Belgium \\
\hline $9 \Phi$ & pAT 9 & 16.7 & Russia \\
\hline 3 & pCA 3 & 4.8 & Ukraine \\
\hline 16 & pCA 16 & 6.8 & Ukraine \\
\hline $23^{\prime}$ & pCA 23' & 8.7 & Ukraine \\
\hline $89^{++}$ & pCA 89 & 15.5 & Belarus \\
\hline
\end{tabular}

The most common group of extrachromosomal elements identified in $P$. carotovorum were $9.8 \mathrm{~kb}$ plasmids and their insertion-deletion variants. The second most common group were $129 \mathrm{~kb}$ plasmids. This group is of a keen interest, but these elements study has certain difficulties, first of all associated with the isolation of large plasmids DNA avoiding gaps in their molecules. Restriction analysis showed that, despite the same size, $129 \mathrm{~kb}$ plasmids differ in restriction patterns [3]. Moreover, strains containing large plasmids were isolated from different ecological niches.

Quite the opposite situation was observed with $9.8 \mathrm{~kb}$ plasmids. Half of the strains containing these plasmids belonged to the same ecological niche (Table 3 ). We assume that these $P$. carotovorum strains ' different origins and large plasmids ' primary sequences data mismatch may be due to the fact that the large extra-chromosomal DNAs play an important role in the pectobacteria pathogenicity formation towards certain host-plants in their respective ecological niches.

P. carotovorum cryptic plasmids pCA25 and pCA25::Tn9, that represented this bacterium most common extra-chromosomal DNA size class, restriction maps were built as a physical mapping result. The transposon marker in the plasmid made possible the restriction sites mutual position specification and Tn9 transposon location within plasmid DNA [4, 5].

Thus, plasmid maintenance is common among phytopathogenic bacteria P. carotovorum strains. Pectobacteria plasmids isolation showed that $30 \%$ of strains contained plasmids of different sizes - from 2.5 to $129 \mathrm{~kb}$. Strains were also characterized by maintenance of two or more plasmids of different sizes 
in one cell. Strains plasmid maintenance was associated with environmental niches where bacteria persisted. Pectobacteria extrachromosomal DNAs are the objects of interest as they may present silent prophage replicons. This study creates the role and importance determination prospect of the autonomous genetic elements in the bacteria P. carotovorum ecology and physiology.

\author{
Ж.Ю. Сергєєва ${ }^{1}$, Ф.I. Товкач \\ ${ }^{1}$ Одеський національний університет ім. I. I. Мечникова, \\ вул. Дворянська, 2, 65082, Одеса, Україна \\ ${ }^{2}$ Інститут мікробіології і вірусологї ім. Д.К. Заболотного НАН України, \\ вул. Академіка Заболотного, 154, 03143, Киї, Украӥна

\section{ПОШИРЕННЯ КРИПТИЧНИХ ПЛАЗМІД ФITOПАТОГЕННОÏ БАКТЕРIÏ РЕCTOBACTERIUM CAROTOVORUM}

У сучасній науковій літературі представлено недостатньо інформації щодо наявності позахромосомних елементів у важливої фітопатогенної бактерії Pectobacterium carotovorum. Дані про плазмідоутримання пектобактерій носять випадковий характер. Метою дослідження було вивчення плазмідних спектрів, їхнього поширення та загальна характеристика криптичних плазмід P. carotovorum. Матеріали та методи. У ході дослідження було проведено скринінг плазмідних спектрів 54 штамів різного походження. Для виділення плазмідних ДНК використовувався стандартний лужний метод Кадо і Лiу [Kado CJ, Liu S-T. Rapid procedure for detection and isolation of large and small plasmids. J. Bacteriol. 1981; 145 (3): 1365-1373]. Результати. У ході дослідження було встановлено, що в даній індивідуальній виборці 16 досліджених штамів містять плазміди різних розмірів. Виявлені плазміди пектобактерій належать до чотирьох дискретних розмірних класів: 2,5-6,8, 9,8-16,7, 47,7-64,5 і 129 т.П.н. Приблизно 50 \% виділених плазмід P. carotovorum відносяться до другого дискретного класу і мають розмір 8,7-10,4 т.п.н. У результаті рестрикційного аналізу великих плазмід 3 однаковим розміром 129 т.п.н. чотирьох різних штамів P. carotovorum виявлено, що ДНК кожної плазміди має унікальну первинну послідовність. Висновки. Результати з виявлення плазмід пектобактерій збігаються з отриманими раніше даними про те, що 30 \% штамів пектобактерій містять плазміди [Tovkach FI. [Isolation and preliminary characterization of cryptic plasmids from Erwinia carotovora]. Microbiology. 2001; 70 (6): 804-810. Russian]. Плазмідоутримання штамів пов'язане з екологічними нішами, в яких персістують бактерії. Позахромосомні ДНК пектобактерій можуть являти собою мовчазні «егоїстичні», можливо профагові, реплікони.

Ключові слова: Pectobacterium carotovorum, криптичні плазміди, рестрикційний аналіз, екологія, плазмідний спектр виду. 


\section{Ж.Ю. Сергеева ${ }^{1}$ Ф.И. Товкач ${ }^{2}$ \\ ${ }^{1}$ Одесский национальный университет им. И.И. Мечникова, ул. Дворянская, 2, 65082, Одесса, Украина \\ ${ }^{2}$ Институт микробиологии и вирусологии им. Д.К. Заболотного НАН Украины, ул. Академика Заболотного, 154, 03143, Киев, Украина \\ РАСПРОСТРАНЕНИЕ КРИПТИЧЕСКИХ ПЛАЗМИД ФИТОПАТОГЕННОЙ БАКТЕРИИ РЕСТOBACTERIUM CAROTOVORUM}

В современной научной литературе представлено недостаточно информации относительно встречаемости внехромосомных элементов у важной фитопатогенной бактерии Pectobacterium carotovorum. Данные о плазмидном содержании пектобактерий носят случайный характер. Целью исследования было изучение плазмидных спектров, их распространения и общая характеристика криптических плазмид P. carotovorum. Материалы и методы. В ходе исследования был проведён скрининг плазмидных спектров 54 штаммов различного происхождения. Для выделения плазмидных ДНК использовался стандартный щелочной метод Кадо и Лиу [Kado CJ, Liu S-T. Rapid procedure for detection and isolation of large and small plasmids. J. Bacteriol. 1981;145(3):1365-1373]. Результаты. В ходе исследования было установлено, что в данной индивидуальной выборке 16 исследованных штаммов содержат плазмиды различных размеров. Обнаруженные плазмиды пектобактерий принадлежат к четырём дискретным размерным классам: 2,5-6,8, 9,8-16,7, 47,7-64,5 и 129 т.п.н. Приблизительно 50 \% выделенных плазмид $P$. carotovorum относятся ко второму дискретному классу и имеют размер 8,7-10,4 т.п.н. В результате рестрикционного анализа больших плазмид с одинаковым размером 129 т.п.н. четырёх различных штаммов P. carotovorum выявлено, что ДНК каждой плазмиды имеет уникальную первичную последовательность. Выводы. Результаты по выявлению плазмид пектобактерий совпадают с полученными ранее данными о том, что 30 \% штаммов пектобактерий содержат плазмиды [Tovkach FI. [Isolation and preliminary characterization of cryptic plasmids from Erwinia carotovora]. Microbiology. 2001; 70 (6): 804-810. Russian]. Плазмидосодержание штаммов связано с экологическими нишами, в которых персистируют бактерии. Внехромосомные ДНК пектобактерий могут представлять собой молчащие «эгоистичные», возможно профаговые, репликоны.

Ключевые слова: Pectobacterium carotovorum, криптические плазмиды, рестрикционный анализ, экология, плазмидный спектр вида.

1. Sergieieva ZhYu, Burova LM, Tovkach FI. [Introduction of transposon Tn9 to endogenic plasmids of Erwinia carotovora at lysogenization of cells by coliphage P1]. Mikrobiol Z. 2006; 68 (4): 34-39. Ukrainian.

2. Sergieieva ZhYu, Tovkach FI. [Distribution of Erwinia carotovora `s extrachromosomal circular DNA]. Rep. of the NASU. 2008; 12: 149-153. Ukrainian.

3. Sergieieva ZhYu, Tovkach FI. [The comparative DNA restriction analysis of Erwinia carotovora megaplasmids and bacteriophages]. Microbiology and biotechnology. 2009; 2 (6): 23-27. Ukrainian.

4. Sergieieva ZhYu, Tovkach FI. [Restriction site mapping of Erwinia carotovora extrachromosomal element pCA25]. Microbiology and biotechnology. 2009; 2 (6): 66-68. Ukrainian. 
5. Sergieieva ZhYu, Tovkach FI. [Restriction site mapping of Erwinia carotovora's extrachromosomal element pCA25]. Rep. of the NASU. 2009; 11: 160-164. Ukrainian.

6. Sergieieva ZhYu, Ivanytsya VO. [Phytopathogenic bacteria of Erwinia, Ralstonia, Agrobacterium genera plasmid profiles studied by different methods]. Microbiology and biotechnology. 2014; 4 (28): 36-43. Ukrainian.

7. Tovkach FI. [Isolation and preliminary characterization of cryptic plasmids from Erwinia carotovora]. Microbiology. 2001; 70 (6): 804-810. Russian.

8. Barnard AML, Bowden SD, Burr T. Quorum sensing, virulence and secondary metabolite production in plant soft-rotting bacteria. Phil. Trans. R. Soc. B. 2007; 362: 1165-1183.

9. Kado CJ, Liu S-T. Rapid procedure for detection and isolation of large and small plasmids. J. Bacteriol. 1981; 145 (3):1365-1373.

10. Nomura N, Yamashita M, Murooka Y. Genetic organization of a DNA-processing region required for mobilization of a non-self-transmissible plasmid, $\mathrm{pEC} 3$, isolated from Erwinia carotovora subsp. carotovora. Gene. 1996; 170 (1): 57-62.

11. Perombelon MCM. Potato diseases caused by soft rot erwinias: an overview of pathogenesis. Plant Pathol. 2002; 51 (1): 1-12.

12. Sherley M, Gordon DM, Collignon PJ. Species differences in plasmid carriage in the Enterobacteriaceae. Plasmid. 2003; 49 (1): 79-85.

13. Toth IK, Bell KS, Holeva MC. Soft rot erwiniae: from genes to genomes. Mol. Plant Pathol. 2003; 1 (4):17-30.

14. Yap M-N, Barak JD, Charkowski AO. Genomic diversity of Erwinia carotovora subsp. carotovora and its correlation with virulence. Appl. and Environ. Microbiol. 2004; 70 (5): 3013-3023.

Отримано 29.09.2016 